\title{
Low molecular weight heparin suppresses tissue factor- mediated cancer cell invasion and migration in vitro
}

\author{
CAMILLE ETTELAIE $^{1}$, DONNA FOUNTAIN ${ }^{1}$, MARY ELIZABETH W. COLLIER ${ }^{1}$, \\ ELLIE BEEBY $^{1}$, YU PEI XIAO ${ }^{2}$ and ANTHONY MARAVEYAS ${ }^{2}$ \\ ${ }^{1}$ Biomedical Section, Department of Biological Sciences, and ${ }^{2}$ Division of Cancer, Postgraduate Medical Institute \\ in association with Hull York Medical School, University of Hull, Hull, HU6 7RX, UK
}

Received November 12, 2010; Accepted January 18, 2011

DOI: $10.3892 /$ etm.2011.211

\begin{abstract}
Elevated expression of tissue factor (TF) has been associated with an increased risk of thrombosis in the majority of cancers. Moreover, treatment of cancer patients with low molecular weight heparin (LMWH) appears to have beneficial effects that reach beyond controlling the immediate hypercoagulable state. In this study, we investigated the influence of the treatment of cancer cells with LMWH $(0-2,000 \mu \mathrm{g} / \mathrm{ml})$ on cell invasiveness and migration in cancer cell lines from five separate tissues; pancreatic, breast, colocarcinoma, ovarian and melanoma. The rate of cell invasion across collagen IV-coated membranes was suppressed in all cell lines tested on incubation with 2,000 $\mu \mathrm{g} / \mathrm{ml} \mathrm{LMWH}$, but BxPC-3 and MDA-MB-231 cells also responded to the lowest concentration of $20 \mu \mathrm{g} / \mathrm{ml} \mathrm{LMWH}$. Furthermore, the rate of cell migration was reduced to varying extents in all of the cell lines tested on incubation with $20 \mu \mathrm{g} / \mathrm{ml}$ or higher concentrations of LMWH. The decrease in the rates of invasion and migration also strongly correlated with the reduction in TF protein expression and TF activity in these cells following incubation with LMWH. Moreover, the LMWH-mediated decreases in cellular invasion in the most affected cell lines (BxPC-3 and MDA-MB-231) were restored by transfection of the cells with the mammalian pCMV-XL5-TF expression vector allowing independent overexpression of TF. In conclusion, LMWH appears to suppress the rate of cancer cell invasion and migration in vitro, through a mechanism that is
\end{abstract}

Correspondence to: Dr Camille Ettelaie, Biomedical Section, Department of Biological Sciences, University of Hull, Cottingham Road, Hull, HU6 7RX, UK

E-mail: c.ettelaie@hull.ac.uk

Abbreviations: TF, tissue factor; LMWH, low molecular weight heparin; NF- $\kappa \mathrm{B}$, nuclear factor $\kappa \mathrm{B}$; ELISA, enzyme-linked immunosorbent assay; ANOVA, analysis of variance; bFGF, basicfibroblast growth factor

Key words: tissue factor, low molecular weight heparin, cell invasion, cell migration at least in part dependent on the TF protein expression and activity in cancer cells.

\section{Introduction}

The association between increased tissue factor (TF) expression and aggressiveness of cancer is well established. The expression of $\mathrm{TF}$ has been correlated with the histological grade of tumours (1), and the up-regulation of TF expression in cancer cells occurs early during the disease (2). Furthermore, the ability of TF to induce cellular cancer cell proliferation, migration and invasion has been documented (3-7). Heparin treatment of cancer patients has been used as a means of controlling the risk of thrombotic episodes (8), and low molecular weight heparin (LMWH) has been reported to be suitable for the regulation of the procoagulant action of TF (9). There is data that incubation of cancer cell lines with LMWH results in the suppression of TF expression. Additionally, we previously reported a reduction in the levels of circulating TF in the plasma from pancreatic cancer patients receiving prophylactic LMWH (Daltaparin), compared to those not receiving the treatment (10). In this study, we further demonstrated the ability of LMWH to reduce the level of TF antigen and activity in cell lines from five separate tissues; BxPC-3 (pancreatic cancer), MDA-MB-231 (breast cancer), LoVo (colorectal cancer), SKOV-3 (ovarian cancer) and A375 (melanoma). Crucially, we report that the incubation of these cancer cell lines with LMWH $(20-2,000 \mu \mathrm{g} / \mathrm{ml})$ reduces cellular invasion and migration through a TF-mediated mechanism in vitro.

\section{Materials and methods}

Cell culture. The pancreatic cell line BxPC-3 (LGC-ATCC, Teddington, UK) was cultured in RPMI-1640 medium, the MDA-MB-231 breast cancer cell line was cultured in Leibovitz's L-15 medium, the LoVo colocarcinoma cell line was cultured in F-12K medium, the SKOV-3 ovarian cancer cell line was cultured in McCoy's 5a medium and the A375 malignant melanoma cell line was cultured in Dulbecco's modified Eagle's medium. All media contained $10 \%$ (v/v) foetal calf serum (FCS) and $1 \%$ (v/v) antibiotic/antimycotic solution. The expression and activity of TF in these cells was confirmed 
Table I. Analysis of the influence of LMWH on TF antigen expression and activity.

A, TF antigen in ng per $10^{6}$ cells

\begin{tabular}{lrrrrr}
\hline LMWH conc. $(\mu \mathrm{g} / \mathrm{ml})$ & BxPC-3 & LoVo & MDA-MB-231 & SKOV-3 & \multicolumn{1}{c}{ A375 } \\
\hline 0 & $112.3 \pm 15.5$ & $116.4 \pm 14.6$ & $135.0 \pm 7.6$ & $94.4 \pm 8.9$ & $100.8 \pm 4.4$ \\
20 & $81.5 \pm 6.0^{\mathrm{a}}$ & $96.6 \pm 14.6$ & $75.1 \pm 8.9^{\mathrm{a}}$ & $83.0 \pm 6.6$ & $85.5 \pm 2.3$ \\
200 & $81.0 \pm 8.4^{\mathrm{a}}$ & $85.0 \pm 17.4^{\mathrm{a}}$ & $29.1 \pm 3.9^{\mathrm{a}}$ & $12.6 \pm 8.2^{\mathrm{a}}$ & $82.7 \pm 3.0$ \\
2000 & $80.2 \pm 3.8^{\mathrm{a}}$ & $71.5 \pm 12.5^{\mathrm{a}}$ & $27.2 \pm 3.6^{\mathrm{a}}$ & $12.6 \pm 3.3^{\mathrm{a}}$ & $58 \pm 6.8^{\mathrm{a}}$ \\
\hline
\end{tabular}

$\mathrm{B}, \mathrm{TF}$ activity in equivalent units of TF per $10^{6}$ cells

\begin{tabular}{lccccc}
\hline LMWH conc. $(\mu \mathrm{g} / \mathrm{ml})$ & BxPC-3 & LoVo & MDA-MB-231 & SKOV-3 & A375 \\
\hline 0 & $250.6 \pm 10$ & $432 \pm 35$ & $250 \pm 16$ & $207 \pm 11$ & \pm 221 \\
20 & $213.8 \pm 12^{\mathrm{a}}$ & $385 \pm 30$ & $180 \pm 25^{\mathrm{a}}$ & $205 \pm 9$ & \pm 209 \\
200 & $195.7 \pm 17^{\mathrm{a}}$ & $258 \pm 13^{\mathrm{a}}$ & $160 \pm 3^{\mathrm{a}}$ & $120 \pm 8^{\mathrm{a}}$ & \pm 182 \\
2000 & $179.8 \pm 18^{\mathrm{a}}$ & $235 \pm 28^{\mathrm{a}}$ & $150 \pm 7^{\mathrm{a}}$ & $100 \pm 1^{\mathrm{a}}$ & $\pm 143^{\mathrm{a}}$ \\
\hline
\end{tabular}

C, Correlation between TF antigen and TF activity

\begin{tabular}{|c|c|c|c|c|c|}
\hline & BxPC-3 & LoVo & MDA-MB-231 & SKOV-3 & A 375 \\
\hline $\begin{array}{l}\text { TF activity } \\
\text { vs. TF antigen }\end{array}$ & 0.896 & $0.949^{\mathrm{a}}$ & $0.977^{\mathrm{a}}$ & $0.986^{\mathrm{a}}$ & $0.962^{\mathrm{a}}$ \\
\hline
\end{tabular}

Sets of cells $\left(10^{6}\right)$ were incubated with a range of LMWH concentrations $(0-2,000 \mu \mathrm{g} / \mathrm{ml})$ for $24 \mathrm{~h}$. (A) The cells were lysed and analysed by ELISA and TF concentrations were determined from a standard curve prepared alongside. Data represent the average of four experiments measured in duplicates ( ${ }^{\mathrm{a}} \mathrm{p}<0.05$ vs. untreated sample). (B) The cells were resuspended in PBS $\left(2 \times 10^{5}\right.$ cells $\left./ 20 \mu 1\right)$ and TF activity was measured using a chromogenic assay. The absorption values were then converted into equivalent concentrations from a standard curve. Data represent the average of four experiments measured in duplicates ( ${ }^{\mathrm{a}} \mathrm{p}<0.05$ vs. untreated sample). (C) Pearson correlation between cell TF antigen and TF activity was calculated using SPSS package $\left({ }^{\mathrm{a}} \mathrm{p}<0.05\right)$.

as below. Cells were supplemented with a range of LMWH concentrations $(20-2,000 \mu \mathrm{g} / \mathrm{ml})(\mathrm{Mr} \sim 3,000)$ (Sigma Chemical Company Ltd., Poole, UK) with the stock lyophilised reagent containing $\sim 60 \mathrm{U} / \mathrm{mg}$ of heparin activity. A set of BxPC-3 and MDA-MB-231 cells were also transfected with the pCMVXL5-TF plasmid (Origene/Cambridge Bioscience, Cambridge, $\mathrm{UK}$ ) to overexpress full-length TF and were used alongside in the invasion assays. The transfection of the plasmid was carried out using Lipofectin (Invitrogen, Paisley, UK) according to the manufacturer's instructions and confirmed prior to experiments by measuring increased TF expression.

Measurement of TF antigen and activity. Sets of cells $\left(10^{6}\right)$ were incubated with a range of LMWH concentrations $(0-2,000 \mu \mathrm{g} / \mathrm{ml})$ for $24 \mathrm{~h}$. The cells were lysed in the presence of a protease inhibitor cocktail (Active Motif, Rixensart, Belgium), and $20 \mu \mathrm{g}$ of the samples was analysed using a TF-antigen ELISA kit (Affinity Biologicals, Ancaster, Canada) as previously described (14). The TF concentrations were determined against a standard curve prepared simultaneously using recombinant TF (0-200 ng/ml) (American Diagnostica Inc., Stamford, USA). Cellular TF activities were quantified using a chromogenic assay based on measuring the activity of generated thrombin, as previously described (15).
Cell invasion and migration assays. The invasion assay relies on the ability of cells to digest through a thin layer of collagen-IV $(1 \mathrm{mg} / \mathrm{ml})$ and traverse a membrane to the lower chamber. Boyden chambers ( $8 \mu \mathrm{m}$ pore size) (VWR International Ltd., Leicestershire, UK) were coated with collagen-IV (Sigma). Each cell type (10 $10^{5}$ in $20 \mu \mathrm{l}$ of media) was in turn placed in the upper chamber and made up to $250 \mu \mathrm{l}$ with media containing a range of LMWH concentrations $(0-2,000 \mu \mathrm{g} / \mathrm{ml})$. In addition, samples of BxPC-3 and MDA-MB-231 cells were transfected with pCMV-XL5-TF to overexpress $\mathrm{TF}$ and included alongside and treated with LMWH $(2,000 \mu \mathrm{g} / \mathrm{ml})$. Complete media (250 $\mu \mathrm{l})$, containing $5 \mu \mathrm{g} / \mathrm{ml}$ of bFGF (Sigma), was placed in the lower chamber, and the cells were incubated at $37^{\circ} \mathrm{C}$ for $24 \mathrm{~h}$. The cells on the upper side of the chamber were then scraped off and the membrane washed with PBS prior to staining with crystal violet solution (Active Motif) for $30 \mathrm{~min}$. The cells were then washed three times with PBS, and 10 fields of view were counted manually. As a quantitative measurement, the cell-associated crystal violet was released from the cells by incubation with $1 \%(\mathrm{w} / \mathrm{v})$ SDS $(200 \mu \mathrm{l})$ for $1 \mathrm{~h}$. The samples were diluted to $1 \mathrm{ml}$, and the absorption was measured at $595 \mathrm{~nm}$. A standard curve was prepared using $0-2 \times 10^{5}$ cells, which were placed in a 24 -well plate, permitted to adhere for 
$2.5 \mathrm{~h}$ and then quantified with crystal violet as above. The correlation between the number of cells and measured absorption in the standard curve was 0.983 .

The migration assay employed relies on unhindered transition of cells towards a bFGF-impregnated collagen-I gel in a flat chamber. Collagen-I in acetic acid was diluted to $0.08 \%(\mathrm{w} / \mathrm{v})$ and neutralised with $1 \mathrm{M} \mathrm{NaOH} / 0.1 \mathrm{M}$ sodium bicarbonate solution. bFGF $(2 \mu \mathrm{g} / \mathrm{ml})$ was then added to the gel, and $20-\mu 1$ aliquots were placed at one side of $10-\mathrm{mm}^{2}$ Cultureslides (BD Bioscience, Oxford, UK) and allowed to set, keeping the slide at an angle of $45^{\circ}$ to prevent dispersion. After the gels had set into a strip, BxPC- 3 cells $\left(2 \times 10^{4}\right.$ in $20 \mu \mathrm{l}$ of media) were placed at the opposite side of the Cultureslides and incubated at $37^{\circ} \mathrm{C}$, keeping the slide at an angle of $45^{\circ}$ until the cells had adhered. The chambers were then supplemented with $200 \mu 1$ of media containing a range of LMWH concentrations $(0-2,000 \mu \mathrm{g} / \mathrm{ml})$ and incubated at $37^{\circ} \mathrm{C}$ for $24 \mathrm{~h}$. Following the incubation, the cells were washed with PBS, fixed with $3 \%$ (v/v) glutaraldehyde and stained with crystal violet; the distance that the cells migrated from the side where they were seeded out was measured in $\mathrm{mm}$.

Statistical analysis. Unless otherwise stated, all values presented are the mean value from the number of experiments stated, together with the derived standard error of mean. Statistical analysis was carried out using the Statistical Package for the Social Sciences (SPSS Inc., Chicago, IL, USA). One-way ANOVA procedure was used for the analysis of variance of data. Pearson coefficient analysis was used to determine any correlation between the observations.

\section{Results}

Influence of LMWH on cellular TF expression and activity. Prior to the study, the expression of TF in all five cell lines was confirmed, and the cells were shown to exhibit a significant amount of TF mRNA, antigen and cell surface activity (Table IA and B). Incubation of the cells with LMWH (20, 200 or $2,000 \mu \mathrm{g} / \mathrm{ml}$ ) for $24 \mathrm{~h}$ resulted in reduction in the detectable TF antigen and TF activity in all of the cell lines. Furthermore, there were strong correlations between the level of TF antigen and activity in these cells, indicating that the TF present on the cancer cells was active and was not encrypted (Table IC).

Influence of LMWH on cell invasion. The rate of invasion of the cells $\left(10^{5}\right)$ across a collagen-IV-coated membrane in the presence of LMWH $(0-2,000 \mu \mathrm{g} / \mathrm{ml})$ at $24 \mathrm{~h}$ (Fig. 1) was reduced over the range of $\mathrm{LMWH}$ tested in all cell lines. The greatest inhibition of invasion was observed in BxPC-3 and MDA-MB-231 cells in the presence of 2,000 $\mu \mathrm{g} / \mathrm{ml} \mathrm{LMWH}$. Consequently, TF was overexpressed in these cell lines and the influence of LMWH on cell invasion was examined. The overexpression of TF in the BxPC-3 or MDA-MB-231 cells overcame the inhibitory effect of LMWH $(2,000 \mu \mathrm{g} / \mathrm{ml})$ on cell migration (Figs. 1A and 2).

Influence of LMWH on cell migration. The migration rate of cells towards a bFGF-impregnated collagen-I gel was reduced in a concentration-dependent manner in the presence of

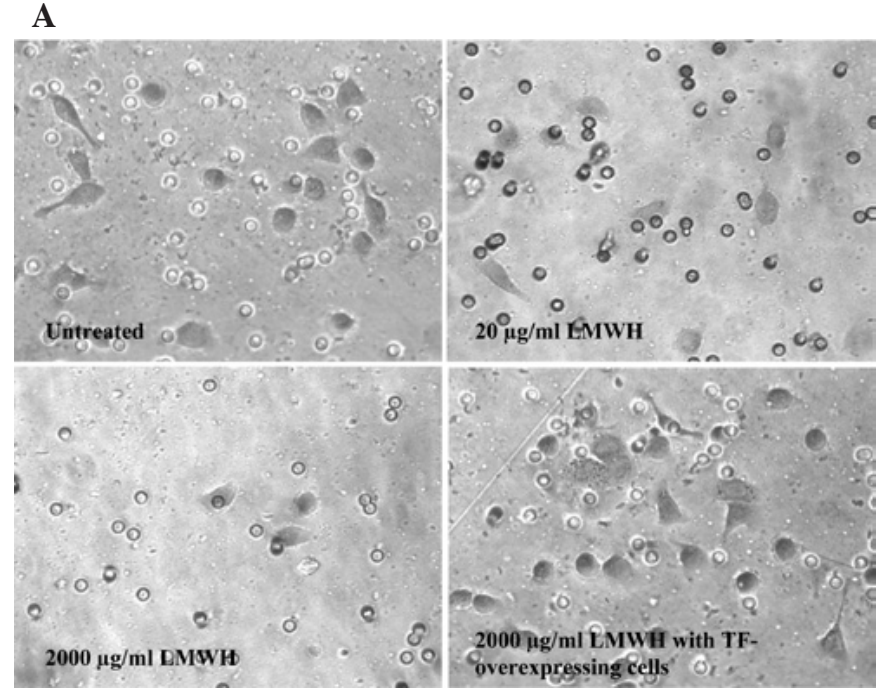

\section{B}
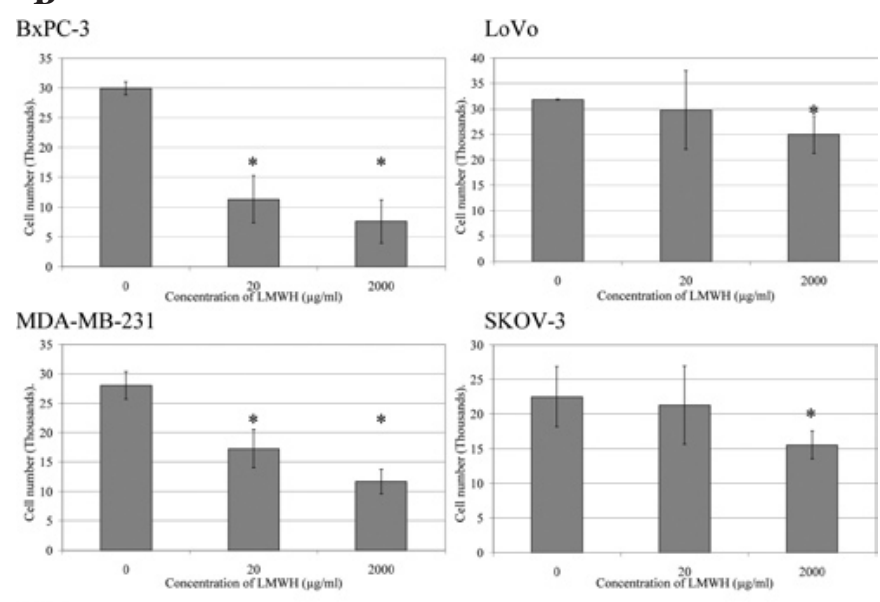

SKOV-3

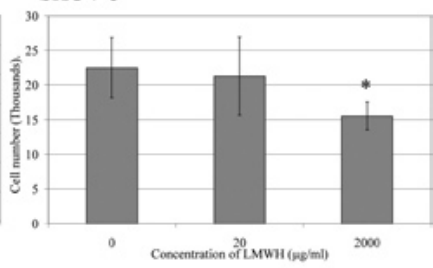

A375

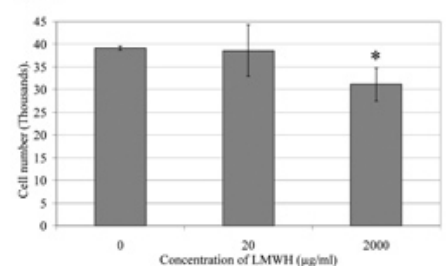

Figure 1. Analysis of the influence of LMWH on cell invasion. Boyden chambers $(8 \mu \mathrm{m})$ were coated with collagen-IV, and cells $\left(10^{5}\right)$ were placed in the upper chambers and made up to $250 \mu 1$ with media containing a range of LMWH concentrations $(0-2,000 \mu \mathrm{g} / \mathrm{ml})$. Media $(250 \mu \mathrm{l})$ containing $5 \mu \mathrm{g} /$ $\mathrm{ml}$ of bFGF were placed in the lower chambers and incubated at $37^{\circ} \mathrm{C}$ for $24 \mathrm{~h}$. The number of cells was then analysed [BxPC-3 cells shown in (A) by staining the cells with crystal violet and counting the cells on the bottom of the membrane]. The crystal violet was then released with $1 \%(\mathrm{w} / \mathrm{v})$ SDS and the absorption of the samples was measured at $595 \mathrm{~nm}$ and quantified against a standard curve at $595 \mathrm{~nm}$ (B). (A) Micrographs are representative of three experiments; (B) the absorption data from which they were averaged are presented ( $\mathrm{p}<0.05$ vs. untreated sample).

LMWH (0-2,000 $\mu \mathrm{g} / \mathrm{ml})$ (Fig. 3). There were strong correlations between both cell invasion and cell migration, with TF antigen and activity in all cells tested (Table II).

\section{Discussion}

The benefits of LMWH in the treatment of cancer patients have previously been reported $(11,12)$. Moreover, the beneficial 


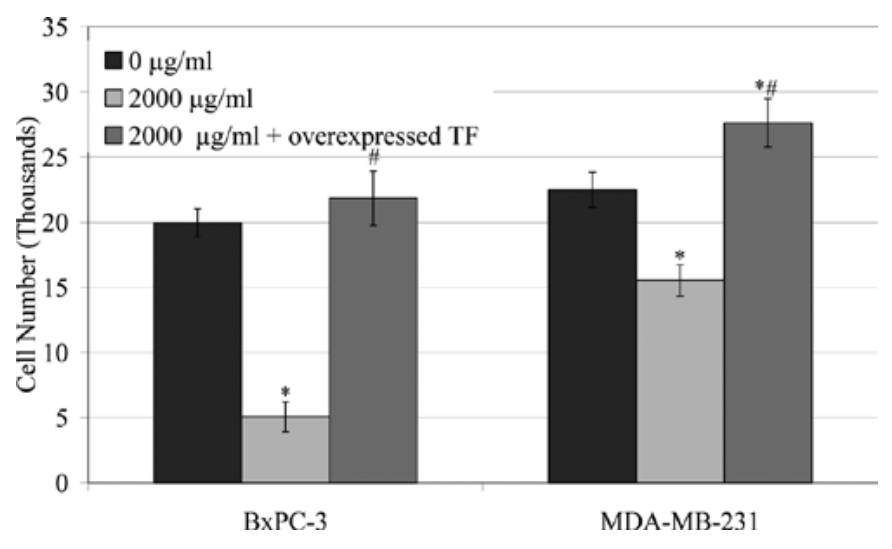

Figure 2. Influence of LMWH on cellular invasion in BxPC-3 and MDAMB-231 cells overexpressing TF. BxPC-3 and MDA-MB-231 cells were transfected with the pCMV-XL5-TF plasmid and permitted to overexpress $\mathrm{TF}$ for $48 \mathrm{~h}$ prior to assaying. Cells $\left(10^{5}\right)$ were placed in the upper chambers of collagen IV-coated Boyden chambers and made up to $250 \mu 1$ with media containing LMWH $(2,000 \mu \mathrm{g} / \mathrm{ml})$. Media $(250 \mu \mathrm{l})$ containing $5 \mu \mathrm{g} / \mathrm{ml}$ of bFGF were placed in the lower chambers and incubated at $37^{\circ} \mathrm{C}$ for $24 \mathrm{~h}$. The number of invading cells was then analysed as in Fig. 1 ("p $<0.05$ vs. respective untransfected/untreated sample; ${ }^{*} \mathrm{p}<0.05$ vs. respective untransfected/ LMWH treated sample).

effects of anticoagulants in cancer patients do not appear to be due to any direct antitumour effects and have been attributed to the suppression of the release of circulating TF $(9,13)$. Furthermore, data obtained from our previous investigation (Ettelaie et al, unpublished data) suggest that LMWH is capable of down-regulating the expression of TF mRNA through a mechanism which appears to involve the suppression of the transcriptional activity of NF- $\mathrm{KB}$. Incubation of the cells with a range of concentrations of LMWH $(20-2,000 \mu \mathrm{g} / \mathrm{ml})$ resulted in a progressive decrease in cell invasion across a collagen-IVcoated membrane, particularly in BxPC-3 and MDA-MB-231 cells (Fig. 1). The reduction in cell invasion correlated with the decrease in TF antigen and activity following incubation of all cell lines with LMWH (Table II). Furthermore, the cellular invasiveness was restored in the BxPC-3 and MDA-MB-231 cell lines upon overexpression of $\mathrm{TF}$ in these cells, even after treatment with LMWH $(2,000 \mu \mathrm{g} / \mathrm{ml})$ (Figs. 1A and 2). Therefore, our data indicate that LMWH may suppress cancer cell invasion through an indirect mechanism, possibly
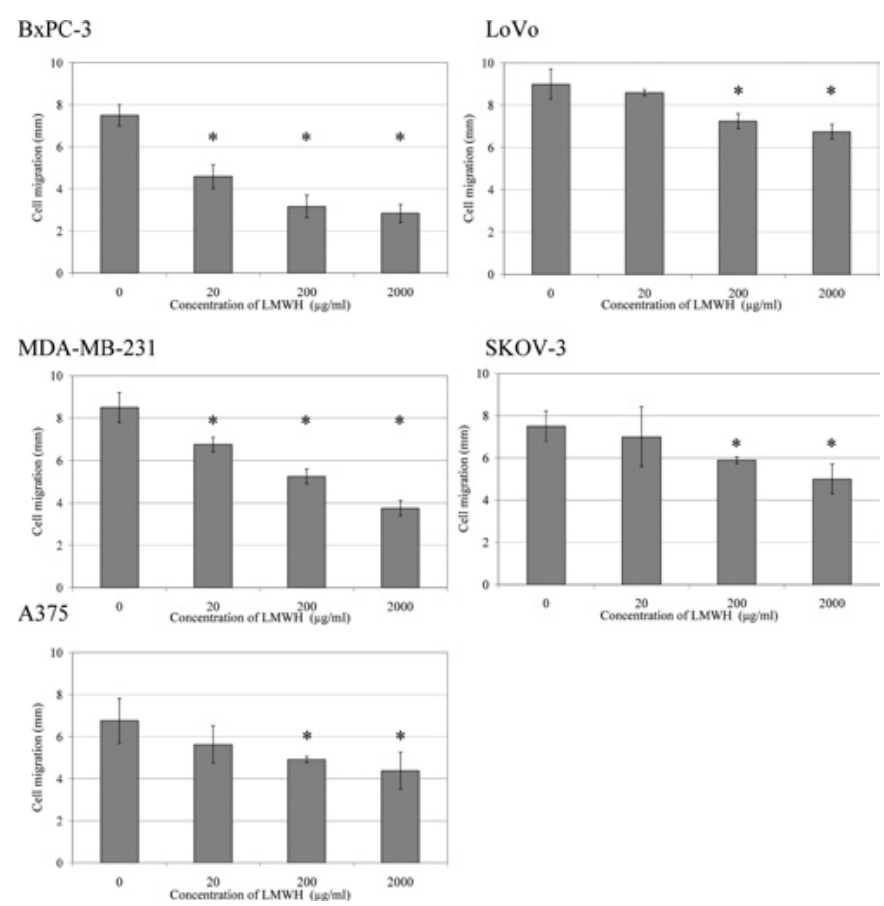

Figure 3. Analysis of the influence of treatment with LMWH on cell migration. Collagen-I gels $[0.08 \%(\mathrm{w} / \mathrm{v})]$ containing bFGF $(2 \mu \mathrm{g} / \mathrm{ml})$ were placed at one side of $10-\mathrm{mm}^{2}$ Cultureslides, and the slides were kept at an angle of $45^{\circ}$ until set. BxPC-3 cells ( $2 \times 10^{4}$ in $20 \mu 1$ of media) were then added to the opposite side of the Cultureslides and kept at an angle of $45^{\circ}$ until adhered. The chambers were then supplemented with $200 \mu 1$ of media containing a range of LMWH concentrations $(0-2,000 \mu \mathrm{g} / \mathrm{ml})$ and incubated at $37^{\circ} \mathrm{C}$ for $24 \mathrm{~h}$. Following the incubation, the cells were fixed with glutaraldehyde, stained with crystal violet and the migration of cells $(\mathrm{mm})$ was measured. Data represent the average of six experiments ( $\mathrm{p}<0.05 \mathrm{vs}$. untreated sample).

by suppressing TF expression and activity. In support of this observation, the up-regulation of metalloproteases by $\mathrm{TF}$ has been documented $(16,17)$. By contrast, the rate of cell migration decreased significantly, even in the presence of a low concentration of LMWH $(20 \mu \mathrm{g} / \mathrm{ml})$, which correlated strongly with reductions in TF antigen and activity (Table II). The ability of TF to induce chemotaxis is well established (3-7). Therefore, it may be suggested that the reduction in TF may contribute to lower rates of metastasis through reduction in cell mobility. In conclusion, the benefits of LMWH therapy

Table II. Analysis of the correlation between cell invasion and cell migration with TF antigen and activity.

\begin{tabular}{lccccr}
\hline & BxPC-3 & LoVo & MDA-MB-231 & SKOV-3 & A375 \\
\hline $\begin{array}{l}\text { Cell invasion } \\
\text { vs. TF antigen }\end{array}$ & $0.990^{\mathrm{a}}$ & 0.987 & $0.994^{\mathrm{a}}$ & $0.994^{\mathrm{a}}$ & 0.963 \\
$\begin{array}{l}\text { Cell invasion } \\
\text { vs. TF activity }\end{array}$ & 0.941 & $0.998^{\mathrm{a}}$ & $0.999^{\mathrm{a}}$ & 0.813 & $0.999^{\mathrm{a}}$ \\
$\begin{array}{l}\text { Cell migration } \\
\text { vs. TF antigen }\end{array}$ & $0.942^{\mathrm{a}}$ & $0.961^{\mathrm{a}}$ & $0.941^{\mathrm{a}}$ & 0.942 & 0.922 \\
$\begin{array}{l}\text { Cell migration } \\
\text { vs. TF activity }\end{array}$ & $0.987^{\mathrm{a}}$ & $0.978^{\mathrm{a}}$ & 0.931 & $0.969^{\mathrm{a}}$ & 0.918 \\
\hline
\end{tabular}

The Pearson correlation between cell invasion or cell migration, with TF antigen or TF activity was calculated using SPSS package ( $\left.{ }^{\mathrm{a}} \mathrm{p}<0.05\right)$. 
may extend beyond the immediate inhibition of coagulation and sustained therapy may be advantageous in limiting the expression of $\mathrm{TF}$ which also diminishes the rate of tumour cell invasion.

\section{References}

1. Kakkar AK, Lemoine NR, Scully MF, Tebbutt S and Williamson RC: Tissue factor expression correlates with histological grade in human pancreatic cancer. Br J Surg 82: 1101-1104, 1995.

2. Khorana AA, Ahrendt SA, Ryan CK, Francis CW, Hruban RH, $\mathrm{Hu}$ YC, Hostetter G, Harvey J and Taubman MB: Tissue factor expression, angiogenesis, and thrombosis in pancreatic cancer. Clin Cancer Res 13: 2870-2875, 2007.

3. Gessler F, Voss V, Dützmann S, Seifert V, Gerlach R and Kögel D: Inhibition of tissue factor/protease-activated receptor- 2 signaling limits proliferation, migration and invasion of malignant glioma cells. Neuroscience 165: 1312-1322, 2010.

4. Jiang X, Zhu S, Panetti TS and Bromberg ME: Formation of tissue factor-factor VIIa-factor Xa complex induces activation of the mTOR pathway which regulates migration of human breast cancer cells. Thromb Haemost 100: 127-133, 2008.

5. Siegbahn A, Johnell M, Sorensen BB, Petersen LC and Heldin $\mathrm{CH}$ : Regulation of chemotax is by the cytoplasmic domain of tissue factor. Thromb Haemost 93: 27-34, 2005.

6. Dorfleutner A, Hintermann E, Tarui T, Takada Y and Ruf W: Cross-talk of integrin alpha3betal and tissue factor in cell migration. Mol Biol Cell 15: 4416-4425, 2004.

7. Sato Y, Kataoka H, Asada Y, Marutsuka K, Kamikubo Y, Koono M and Sumiyoshi A: Overexpression of tissue factor pathway inhibitor in aortic smooth muscle cells inhibits cell migration induced by tissue factor/factor VIIa complex. Thromb Res 94: 401-406, 1999.

8. Khorana AA and Fine RL: Pancreatic cancer and thromboembolic disease. Lancet Oncol 5: 655-663, 2004.

9. Kakkar AK and Williamson RC: Prevention of venous thromboembolism in cancer using low-molecular-weight heparins. Haemostasis 27 (Suppl 1): 32-37, 1997.
10. Maraveyas A, Ettelaie C, Echrish H, Li C, Gardiner E, Greenman $\mathrm{J}$ and Madden L: Weight-adjusted dalteparin for prevention of vascular thromboembolism in advanced pancreatic cancer patients decreases serum tissue factor and serum-mediated induction of cancer cell invasion. Blood Coagul Fibrinolysis 21: 452-458, 2010.

11. Icli F, Akbulut H, Utkan G, Yalcin B, Dincol D, Isikdogan A, Demirkazik A, Onur H, Cay F and Büyükcelik A: Low molecular weight heparin (LMWH) increases the efficacy of cisplatinum plus gemcitabine combination in advanced pancreatic cancer. J Surg Oncol 95: 507-512, 2007.

12. Von Delius S, Ayvaz M, Wagenpfeil S, Eckel F, Schmid RM and Lersch C: Effect of low-molecular-weight heparin on survival in patients with advanced pancreatic adenocarcinoma. Thromb Haemost 98: 434-439, 2007.

13. Gori AM, Pepe G, Attanasio M, Falciani M, Abbate R, Prisco D, Fedi S, Giusti B, Brunelli T, Giusti B, Brunelli T, Comeglio P, Gensini GF and Neri Serneri GG: Tissue factor reduction and tissue factor pathway inhibitor release after heparin administration. Thromb Haemost 81: 589-593, 1999.

14. Li C, Colman LM, Collier ME, Dyer CE, Greenman J and Ettelaie C: Tumour-expressed tissue factor inhibits cellular cytotoxicity. Cancer Immunol Immunother 55: 1301-1308, 2006.

15. Ettelaie C, Su S, Li C and Collier ME: Tissue factor-containing microparticles released from mesangial cells in response to high glucose and AGE induce tube formation in microvascular cells. Microvasc Res 76: 152-160, 2008.

16. Zhang JQ, Wan YL, Liu YC, Wang X, Tang JQ, Wu T, Zhu J and Pan YS: The FVIIa-tissue factor complex induces the expression of MMP7 in LOVO cells in vitro. Int J Colorectal Dis 23: 971-978, 2008.

17. Tang JQ, Wan YL, Liu YC, Rong L, Wang X, Wu T, Pan YS, Ye JM, Yao HW and Zhu J: Role of tissue factor in the invasion of cultured human colon carcinoma cells and its correlation with matrix metalloproteinases. Beijing Da Xue Xue Bao 37: 265-268, 2005. 